\title{
Enhancing the photocatalytic activity and photostability of zinc oxide nanorod arrays via graphitic carbon mediation
}

\author{
Xuewei Zhang a, Xueliang Zhang a, Xin Wang a , Lequan Liu a,b, Jinhua Ye a,b,c, Defa Wang a,b,* \\ a TJU-NIMS International Collaboration Laboratory, Key Lab of Advanced Ceramics and Machining Technology of Ministry of Education, Tianjin Key Lab \\ of Composite and Functional Materials, School of Materials Science and Engineering, Tianjin University, Tianjin 300072, China \\ b Collaborative Innovation Center of Chemical Science and Engineering (Tianjin), Tianjin 300072, China \\ c International Center of Materials Nanoarchitectonics (WPI-MANA), National Institute for Materials Science (NIMS), Ibaraki 305-0044, Japan
}

\section{A R T I C L E I N F}

\section{Article history:}

Received 18 November 2017

Accepted 28 December 2017

Published 5 May 2018

\section{Keywords:}

Photocatalysis

ZnO nanorod array

Graphitic carbon

Charge transfer

Photostability

$\mathrm{CO}_{2}$ reduction

\begin{abstract}
A B S T R A C T
Low optical absorption and photocorrosion are two crucial issues limiting the practical applications of zinc oxide (ZnO)-based photocatalysts. In this paper, we report the fabrication of graphitic-carbon-mediated ZnO nanorod arrays (NRAs) with enhanced photocatalytic activity and photostability for $\mathrm{CO}_{2}$ reduction under visible light irradiation. ZnO NRA/C- $x(x=005,01,02$, and 03) nanohybrids are prepared by calcining pre-synthesized ZnO NRAs with different amounts of glucose $(0.05,0.1,0.2$, and $0.3 \mathrm{~g})$ as a carbon source via a hydrothermal method. X-ray photoelectron spectroscopy reveals that the obtained ZnO NRA/C- $x$ nanohybrids are imparted with the effects of both carbon doping and carbon coating, as evidenced by the detected $\mathrm{C}-\mathrm{O}-\mathrm{Zn}$ bond and the $\mathrm{C}-\mathrm{C}$, $\mathrm{C}-\mathrm{O}$ and $\mathrm{C}=\mathrm{O}$ bonds, respectively. While the basic structure of $\mathrm{ZnO}$ remains unchanged, the UV-Vis absorption spectra show increased absorbance owing to the carbon doping effect in the $\mathrm{ZnO}$ NRA/C- $x$ nanohybrids. The photoluminescence (PL) intensities of ZnO NRA/C- $x$ nanohybrids are lower than that of bare ZnO NRA, indicating that the graphitic carbon layer coated on the surface of the ZnO NRA significantly enhances the charge carrier separation and transport, which in turn enhances the photoelectrochemical property and photocatalytic activity of the ZnO NRA/C- $x$ nanohybrids for $\mathrm{CO}_{2}$ reduction. More importantly, a long-term reaction of photocatalytic $\mathrm{CO}_{2}$ reduction demonstrates that the photostability of ZnO NRA/C- $x$ nanohybrids is significantly increased in comparison with the bare ZnO NRA.
\end{abstract}

(C) 2018, Dalian Institute of Chemical Physics, Chinese Academy of Sciences. Published by Elsevier B.V. All rights reserved.

\section{Introduction}

Photocatalysis using semiconductors and solar energy for water splitting to generate hydrogen and recycling $\mathrm{CO}_{2}$ back to hydrocarbon fuels has attracted wide attention, in view of the global energy crisis and environment pollution issues [1-8]. Over the past four decades, tremendous efforts have been devoted to developing various semiconductor photocatalysts
[6-16], among which zinc oxide ( $\mathrm{ZnO})$ has been intensively studied because of its attractive photophysical properties and nontoxicity [17-20]. However, the practical application of ZnO as a photocatalyst has hardly been realized. This has been because of its low photostability that is caused by photocorrosion [21-24], in which the zinc ion is prone to oxidation by photogenerated holes upon light irradiation. $\mathrm{ZnO}$ is a wide band gap ( $E_{\mathrm{g}} \approx 3.2 \mathrm{eV}$ ) semiconductor, so it can only absorb ultraviolet

\footnotetext{
* Corresponding author. Tel/Fax: +86-22-27405065; E-mail: defawang@tju.edu.cn This work was supported by the National Basic Research Program of China (973 Program, 2014CB239300), the National Natural Science Foundation of China (51572191, 21633004), and the Natural Science Foundation of Tianjin City (13JCYBJC16600).

DOI: 10.1016/S1872-2067(18)63010-4 | http://www.sciencedirect.com/science/journal/18722067 | Chin. J. Catal., Vol. 39, No. 5, May 2018
} 
(UV) wavelengths. UV wavelengths constitute only $\sim 4 \%$ of the solar spectrum, so longer visible wavelengths are effectively wasted [25-27]. Previous studies have shown that doping with $\mathrm{C}, \mathrm{N}$, or $\mathrm{S}$ could extend the optical absorption range of $\mathrm{ZnO}$ into the visible region. Lin et al. [28] prepared hierarchically porous nanoarchitectures of $\mathrm{C}$-doped $\mathrm{ZnO}$ by a facile and inexpensive wet-chemical method. Cho et al. [29] used vitamin C as a carbon source to synthesize $\mathrm{C}$-doped $\mathrm{ZnO}$ as a visible light photocatalyst.

Efficient charge separation and transfer are essential for efficient photocatalytic activity [30,31]. How to suppress the recombination of photoinduced charge carriers (electron/hole pairs) has long been a challenge in photocatalysis [32,33]. A photocatalytic reaction is a surface-based process involving the separation and transport of photoinduced charge carriers, as the subsequent redox reactions mainly occur on the catalyst surface. One-dimensional (1-D) semiconductors have large surface-to-volume ratios and good charge carrier transport rates which benefit from the ballistic effect. Thus, 1-D semiconductors are expected to exhibit superior photocatalytic activity compared with conventional powder photocatalysts $[34,35]$. Coating a thin amorphous carbon layer on the surface of a semiconductor has been demonstrated to effectively improve charge carrier separation. In this context, many recent studies have reported the coating of 1-D $\mathrm{ZnO}$ with a carbon layer to suppress charge carrier recombination, and in turn improve the photocatalytic activity. Mu et al. [36] prepared ZnO-carbon nanofiber heteroarchitectures with high photocatalytic activity for degrading rhodamine B. Han et al. [37] reported the enhanced photocatalytic activity and anti-photocorrosion properties of $\mathrm{ZnO}$ by coupling with versatile carbon species. A microwave-assisted carbonization strategy was adopted by Guo et al. [38] to form a uniform carbon coating on $\mathrm{ZnO}$ nanorods, which enhanced their photocatalytic activity. Yu et al. [39] synthesized $\mathrm{ZnO}$ /carbon quantum dots by a one-step method, and the resulting material exhibited excellent photocatalytic ability for toxic gas degradation under visible light irradiation. Akir et al. [40] synthesized carbon-ZnO nanocomposites with enhanced visible light photocatalytic performance for degrading rhodamine B. Others have synthesized ZnO-nanoparticle/graphene-oxide or ZnO-nanorod/reducedgraphene-oxide composites for the photodegradation of methylene blue $[41,42]$. However, previous studies on carbon-modified $\mathrm{ZnO}$ have rarely focused on comprehensively improving the photostability, charge carrier separation, and photocatalytic $\mathrm{CO}_{2}$ reduction [26].

Herein, we report a modified hydrothermal method for fabricating graphitic-carbon-mediated visible-light-responsive $\mathrm{ZnO}$ nanorod arrays (NRAs). The resulting carbon-containing NRAs exhibit enhanced photocatalytic activity and photostability for $\mathrm{CO}_{2}$ reduction, compared with the NRA containing no carbon. By calcining pre-synthesized ZnO NRAs coated with different amounts of glucose as a carbon source at a suitable hydrothermal temperature, we obtain ZnO NRA/C- $x$ nanohybrids on zinc foil. The ZnO NRA/C- $x$ nanohybrids are imparted with the effects of both carbon doping and carbon coating, so they exhibit increased absorption ability and photostability compared with the ZnO NRA. The graphitic carbon layer coated on the surface of the ZnO NRA significantly enhances charge carrier separation and transport and thus enhances the photocatalytic activity of the ZnO NRA/C- $x$ nanohybrids. This study provides a method involving graphitic carbon mediation for fabricating a highly stable and active $\mathrm{ZnO}$-based photocatalyst for $\mathrm{CO}_{2}$ reduction.

\section{Experimental}

\subsection{Sample preparation}

The $\mathrm{ZnO}$ nanorod array was directly grown on zinc foil $(2.0$ $\mathrm{cm} \times 3.0 \mathrm{~cm}$ ) via a hydrothermal method at $180{ }^{\circ} \mathrm{C}$ for $4 \mathrm{~h}$, in a solution containing $25 \mathrm{~mL}$ of $\mathrm{H}_{2} \mathrm{O}, 2 \mathrm{~g}$ of $\mathrm{NaOH}$, and $3.6 \mathrm{~mL}$ of $30 \% \mathrm{H}_{2} \mathrm{O}_{2}$. The surface of the zinc foil was pretreated using hydrochloric acid for $20 \mathrm{~s}$. After rinsing with deionized water several times, the synthesized ZnO NRA on the zinc foil was dried at room temperature. A typical procedure for coating carbon on the ZnO NRA was as follows. Different amounts of glucose $(0.05,0.1,0.2,0.3 \mathrm{~g})$ were first dissolved in $30 \mathrm{~mL}$ of deionized water, into which the ZnO NRA was added; the resulting solution was then heated to $180{ }^{\circ} \mathrm{C}$ for $4 \mathrm{~h}$, followed by cooling to room temperature. After washing with deionized water several times, the samples were dried in an oven at $80^{\circ} \mathrm{C}$ for $1 \mathrm{~h}$. Finally, the samples were placed in a tube furnace and calcined at $800{ }^{\circ} \mathrm{C}$ with a heating rate of $5{ }^{\circ} \mathrm{C} / \mathrm{min}$ for $3 \mathrm{~h}$ in an argon gas atmosphere, to obtain the resulting samples ZnO-NRA/C- $x$ (where $x=005,01,02$, and 03, and denotes added glucose amounts of $0.05,0.1,0.2$, and $0.3 \mathrm{~g}$, respectively). For comparison, zinc foil coated with graphitic carbon (denoted as $\mathrm{Zn} / \mathrm{C}$ foil) was also prepared following a similar procedure as mentioned above.

\subsection{Characterization}

The crystal structures of the synthesized samples were determined using a powder X-ray diffractometer (XRD; $\mathrm{Cu} K_{\alpha}$ radiation, D8 Advanced, Bruker, Germany). Microstructures were observed using a field-emission scanning electron microscope (FESEM; JOEL-S4800, Japan) and a transmission electron microscope (TEM; FEI Tecnai G2 F20, USA), both equipped with an energy dispersive X-ray spectrometer. Raman scattering spectra were recorded using a Raman spectroscope (XploRA PLUS, HORIBA Scientific, NJ, USA). The optical properties of the samples were characterized by measuring their ultraviolet-visible (UV-Vis) diffuse reflectance spectra with a spectrophotometer (UV-2700, Shimazu, Japan) and photoluminescence (PL) spectra with a fluorescence spectrophotometer (Fluorolog-3, HORIBA Scientific, NJ, USA), respectively. The valence states of near-surface elements were measured by X-ray photoelectron spectroscopy (XPS; Escalab 250, Thermo Scientific, MA, USA). XPS spectra were calibrated using the C $1 \mathrm{~s}$ peak $(284.8 \mathrm{eV})$ as the reference.

\subsection{Evaluation of photoelectrochemical (PEC) and photocatalytic activities}


The PEC performances of the samples were measured using an electrochemical workstation (CHI660E, Shanghai, China) with a conventional three-electrode system, with $\mathrm{Na}_{2} \mathrm{SO}_{4}$ solution $(0.1 \mathrm{~mol} / \mathrm{L})$ as the electrolyte under visible light irradiation. The ZnO NRA/C- $x$ foil sample with an irradiation area of $\sim 2 \mathrm{~cm} \times 2 \mathrm{~cm}$ was used as the working electrode. The counter electrode was platinum $(\mathrm{Pt})$ wire, and the reference electrode was a silver/silver chloride $(\mathrm{Ag} / \mathrm{AgCl})$ electrode. Photocatalytic $\mathrm{CO}_{2}$ conversion over the $\mathrm{ZnO} \mathrm{NRA} / \mathrm{C}-x$ nanohybrids $(2 \mathrm{~cm} \times 3$ $\mathrm{cm}$ ) was carried out in a quartz glass reactor, which was connected to a closed gas circulation and evacuation system. Prior to reaction, $3 \mathrm{~mL}$ of deionized water was injected into the reactor. After evacuating the reaction setup several times, high-purity $\mathrm{CO}_{2}$ gas was introduced into the reaction system until achieving a pressure of $70 \mathrm{kPa}$. Then, the $\mathrm{CO}_{2}$ photoreduction reaction was initiated by exposing the top quartz window of the reactor to visible light. At given time intervals, $0.5 \mathrm{~mL}$ of gas was extracted from the reactor using a precision analytical syringe (Pressure-Lok, USA) and was then quickly injected into a gas chromatograph (GC-14B, Shimadzu, Japan) equipped with a flame ionized detector and methanizer. For comparison, the $\mathrm{Zn} / \mathrm{C}$ foil sample was also used for the photoreduction of $\mathrm{CO}_{2}$ under identical experimental conditions.

\section{Results and discussion}

Scheme 1 illustrates the process used to synthesize the $\mathrm{ZnO}$ NRA/C. First, a well-aligned ZnO NRA was grown directly on a zinc foil substrate using a hydrothermal method at $180^{\circ} \mathrm{C}$ for 4 h, in a solution containing $25 \mathrm{~mL}$ of $\mathrm{H}_{2} \mathrm{O}, 2 \mathrm{~g}$ of $\mathrm{NaOH}$ and 3.6 $\mathrm{mL}$ of $30 \% \mathrm{H}_{2} \mathrm{O}_{2}$ [43]. Then, graphitic carbon-hybridized $\mathrm{ZnO}$ NRA nanocomposites were prepared by a hydrothermal method and subsequent carbonization of the pre-adsorbed glucose.

Fig. 1(a) shows the XRD patterns of the ZnO NRA and ZnO-NRA/C- $x$ nanohybrids with different amounts of carbon $(x$ $=005,01,02,03)$. The XRD patterns of both the ZnO NRA and the ZnO-NRA/C- $x$ nanohybrids were consistent with well-crystallized hexagonal wurtzite ZnO (JCPDS No. 36-1451). All samples were nano-crystalline, but the crystallinity of the ZnO NRA was higher than those of the $\mathrm{ZnO}-\mathrm{NRA} / \mathrm{C}-x$ nanohybrids. The crystallinity of the nanohybrids decreased with increasing amount of glucose used. Similar results were reported by Zhang et al. [25]. No peaks characteristic of graphitic carbon were observed in the XRD patterns, because of the non-crystalline nature of carbon in the nanohybrids. Raman spectra of the ZnO NRA/C nanohybrids showed two peaks at around 1351 and $1597 \mathrm{~cm}^{-1}$ (Fig. 1(b)), which could be assigned to the D band and G band, respectively [44]. No obvious peaks were observed at around 1351 and $1597 \mathrm{~cm}^{-1}$ in the Raman spectrum of the ZnO NRA. The appearance of the D band is generally strong evidence for disorder within the graphitic structure, while the $\mathrm{G}$ band indicates the presence of $s p^{2}$ carbon-type structures [45]. The Raman results confirmed the presence of graphitic carbon in the ZnO NRA/C nanohybrids.

XPS was used to determine the chemical state of $\mathrm{C}$ atoms in the samples. The core level spectrum in Fig. 2 shows a broad asymmetric peak, suggesting the existence of more than one chemical state of $\mathrm{C}$. The $\mathrm{C} 1 \mathrm{~s}$ spectrum could be divided into
Zinc Foil

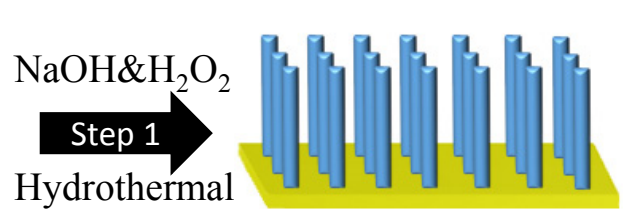

Glucose

Immersion

Step 2

Carbonization

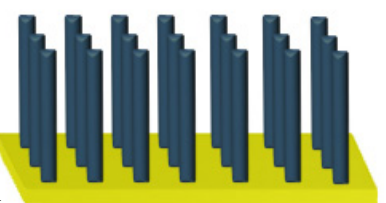

Scheme 1. Process for synthesizing ZnO NRA/C- $x$ via a glucose-assisted two-step route. (1) Formation of a ZnO NRA via hydrothermal synthesis at $180{ }^{\circ} \mathrm{C}$ for $4 \mathrm{~h}$, in a solution containing $25 \mathrm{~mL}$ of $\mathrm{H}_{2} \mathrm{O}, 2 \mathrm{~g}$ of $\mathrm{NaOH}$, and $3.6 \mathrm{~mL}$ of $30 \% \mathrm{H}_{2} \mathrm{O}_{2}$; (2) Formation of $\mathrm{ZnO} \mathrm{NRA} / \mathrm{C}-x$ using glucose for carbonization, by hydrothermal treatment and subsequent calcination in argon gas at $800{ }^{\circ} \mathrm{C}$ for $3 \mathrm{~h}$.
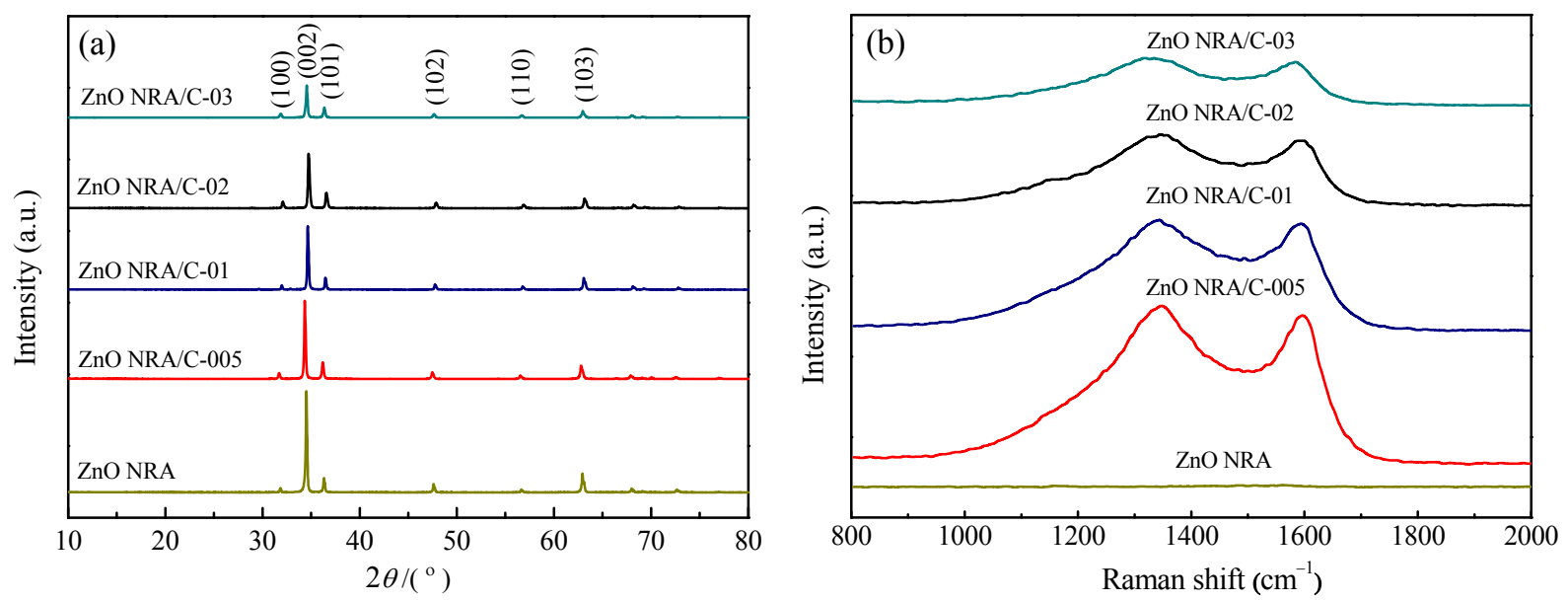

Fig. 1. (a) XRD patterns and (b) Raman spectra of the ZnO NRA and ZnO NRA/C- $x$ nanohybrids. 


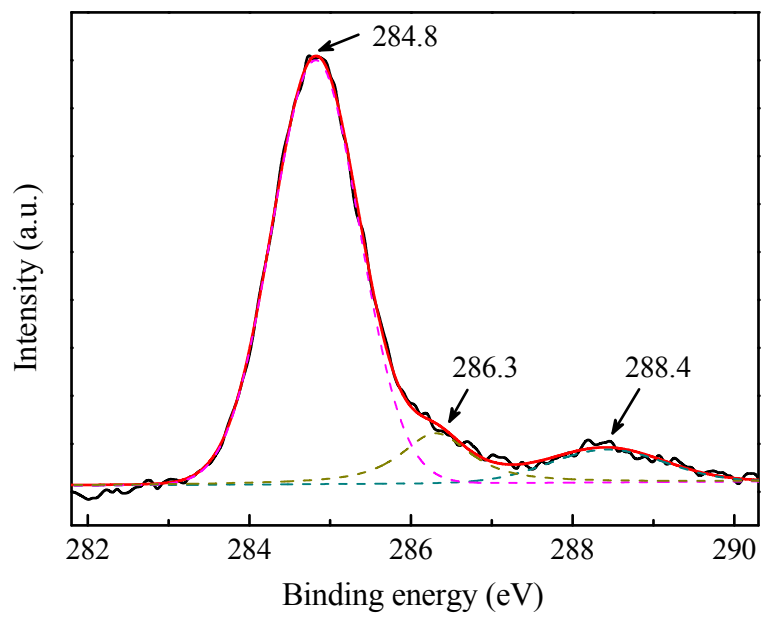

Fig. 2. C $1 s$ XPS spectrum of ZnO NRA/C-01. The sample was obtained by hydrothermal synthesis in a solution of $30 \mathrm{~mL}$ of deionized water and $0.1 \mathrm{~g}$ of glucose at $180{ }^{\circ} \mathrm{C}$ for $4 \mathrm{~h}$, followed by calcination in argon at $800{ }^{\circ} \mathrm{C}$ for $3 \mathrm{~h}$.

three peaks at $284.8,286.3$, and $288.4 \mathrm{eV}$, corresponding to $\mathrm{C}-\mathrm{C}, \mathrm{C}-\mathrm{O}$, and $\mathrm{C}=\mathrm{O}$ bonds, respectively [24]. The binding energy at $284.8 \mathrm{eV}$ was due to graphitic carbon [39]. The peak at 286.3 $\mathrm{eV}$ suggested that carbon was doped into the interstitial positions of the $\mathrm{ZnO}$ lattice, and formed $\mathrm{C}-\mathrm{O}-\mathrm{Zn}$ bonds with $\mathrm{ZnO}$ $[19,27]$. This resulted in a new inter-band above the valence band of $\mathrm{ZnO}$ [20], which is discussed in more detail below.

Doping or coating $\mathrm{ZnO}$ with carbon can influence its light absorption properties $[20,25,37,46]$. Fig. 3(a) shows UV-Vis diffuse reflectance spectra of the samples. The spectrum of the $\mathrm{ZnO}$ NRA showed the characteristic absorption edge of $\mathrm{ZnO}$ at around $\sim 385 \mathrm{~nm}$. After incorporating carbon, the ZnO NRA/C nanohybrids exhibited visible light absorption, as evidenced by the red-shifted absorption edge and the enhanced background absorption in the visible region. Increasing the amount of the carbon coating layer increased the red shift in absorption edge and also increased the background absorption in the visible region. From the plots of $(\alpha h v)^{2}$ versus photon energy shown in Fig. 3(b), the band gaps of the ZnO NRA/C- $x$ nanohybrids were

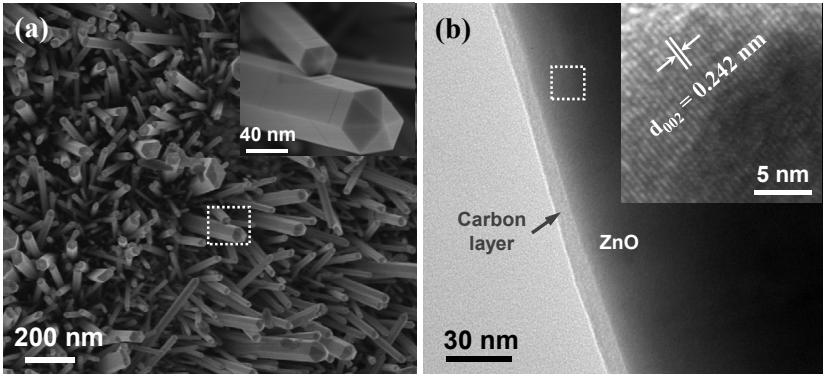

Fig. 4. (a) Typical SEM image and enlarged image (inset) showing the characteristic growth direction [0001] of the ZnO nanorods; (b) TEM image of the ZnO NRA/C-01 nanohybrid and high-resolution TEM image of the ZnO NRA (inset).

calculated to be $3.18,3.17,3.15,3.12$, and $3.05 \mathrm{eV}$ for $x=0,005$, 01,02 , and 03 , respectively. The band gap energy decreased with increasing amount of incorporated carbon. As observed in the XPS results, the visible light absorption of the ZnO NRA/C nanohybrids could be attributed to the doped carbon atoms in $\mathrm{ZnO}$, the C $2 p$ orbital of which formed a new inter-band above the $02 p$ orbital in the valence band of $\mathrm{ZnO}$.

Fig. 4(a) shows a typical SEM image of a ZnO NRA. Individual nanorods had lengths of 2-5 $\mu \mathrm{m}$ and diameters of 400-700 $\mathrm{nm}$. The enlarged image (inset in Fig. 4(a)) shows that the ZnO nanorods were grown along the [0001] direction. This was evidenced by the characteristic feature of their wurtzite structure, i.e. that the tip of each nanorod was constructed from six regular facets of (103) [36]. TEM observations of the ZnO NRA/C-01 nanohybrid showed that the ZnO NRA surface was uniformly coated with an amorphous layer with a thickness of about $8 \mathrm{~nm}$ (Fig. 4(b)). The Raman (Fig. 1(b)) and XPS (Fig. 2) analyses collectively indicated that the amorphous coating was a graphitic carbon layer. The intimate contact of the carbon layer with the ZnO NRA reportedly improves charge separation and thus photocatalytic activity [30,36,47]. The distance between neighboring lattice fringes was measured to be $\sim 0.242$ $\mathrm{nm}$ from the HRTEM image inset in Fig. 4(b). This was very close to the distance between two adjacent $\mathrm{ZnO}(002)$ crystal planes.
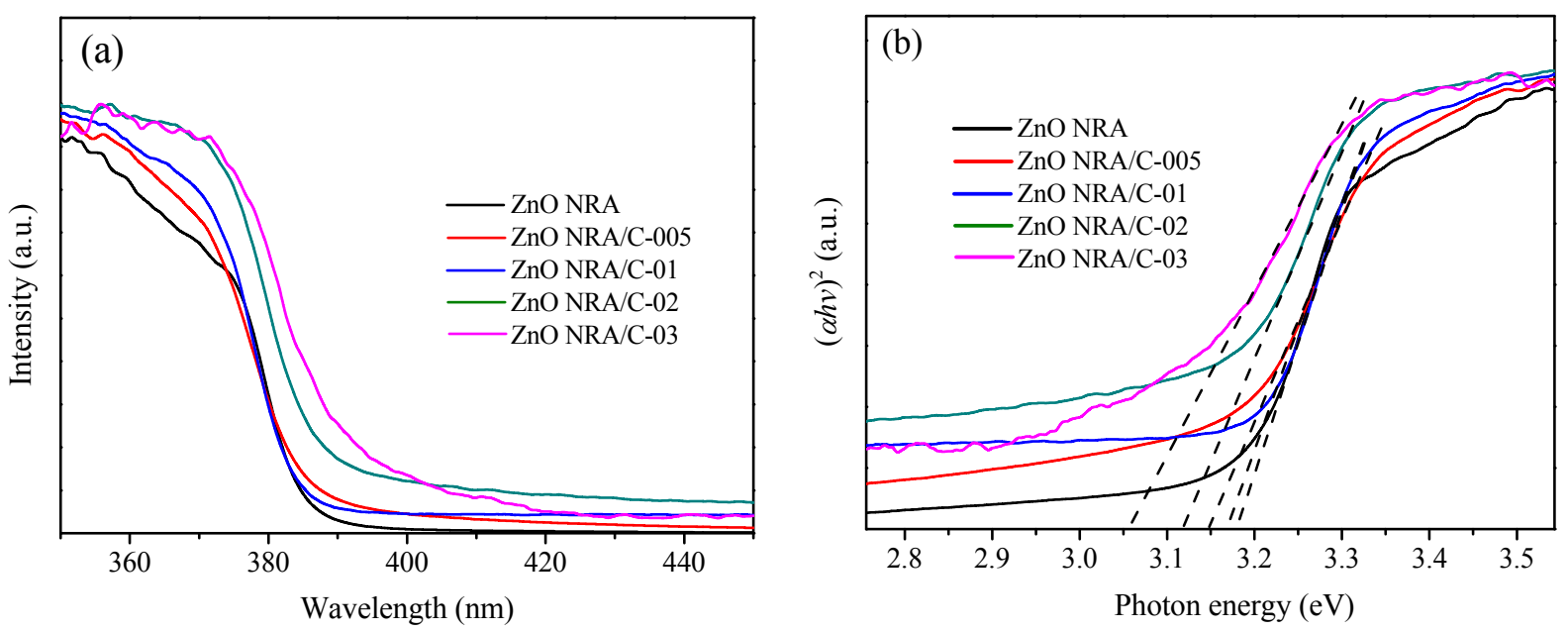

Fig. 3. (a) UV-Vis diffuse reflectance spectra and (b) plots of $(\alpha h v)^{2}$ versus photon energy of the ZnO NRA and ZnO NRA/C- $x$. 

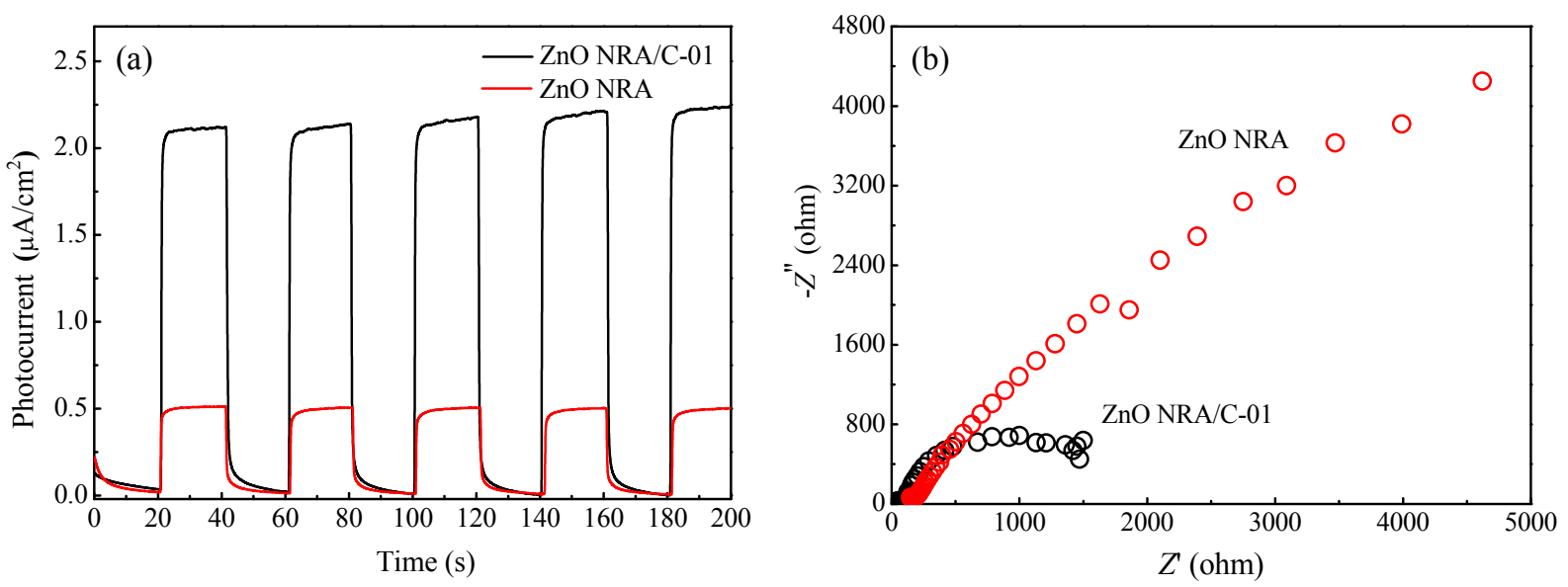

Fig. 5. (a) Transient photocurrent responses of the ZnO NRA and ZnO NRA/C-01 electrodes at $0.5 \mathrm{~V}$ vs. Ag/AgCl under visible light irradiation; (b) EIS Nyquist plots of the ZnO NRA and ZnO NRA/C-01 electrodes at $0.5 \mathrm{~V}$ vs. Ag/AgCl, at frequencies of 100-105 Hz.

To investigate the effect of carbon modification on the performance of the ZnO NRA, PEC measurements of the ZnO NRA and $\mathrm{ZnO}$ NRA/C-01 were carried out. Comparison of these measurements allowed the effect of the interaction between the ZnO NRA and graphitic carbon to be probed. Fig. 5(a) shows transient photoresponses measured under visible light irradiation. The photocurrent of ZnO NRA/C-01 $\left(\sim 2.2 \mu \mathrm{A} / \mathrm{cm}^{2}\right)$ was about 4.4 times higher than that of the ZnO NRA $\left(\sim 0.5 \mu \mathrm{A} / \mathrm{cm}^{2}\right)$, which indicated the efficient electron-hole separation in $\mathrm{ZnO}$ NRA/C-01. Electrochemical impedance spectroscopy (EIS) was used to elucidate the charge transfer behavior (i.e., separation efficiency of charge carriers) in the samples. The EIS Nyquist plots in Fig. 5(b) show that the semicircle of ZnO NRA/C-01 was much smaller than that of the ZnO NRA. This indicated more efficient interfacial electron transfer in ZnO NRA/C-01, as a result of the existence of carbon [48]. Carbon modification significantly enhanced the separation and transport of photogenerated charge carriers in the ZnO NRA/C-01 nanohybrid [36,39].

Efficient charge separation is important for enhanced photocatalytic activity $[33,49,50]$. PL measurements were used to further investigate the transfer behavior of photoinduced electrons. Fig. 6 shows PL spectra of the ZnO NRA and ZnO NRA/C-01 nanohybrid, excited at a wavelength of $275 \mathrm{~nm}$. The PL intensity of ZnO NRA/C-01 was significantly lower than that of the ZnO NRA, because of the quenching effect of the carbon layer coating the $\mathrm{ZnO} \mathrm{NRA}$. The quenching effect in $\mathrm{ZnO}$ NRA/C-01 resulted in the rapid transfer of photoelectrons from the ZnO NRA to the carbon layer. In other words, the carbon layer coated on the ZnO NRA suppressed the recombination of photoinduced charge carriers [51], thus enhancing the photocatalytic activity of ZnO NRA/C-01.

Photocatalytic $\mathrm{CO}_{2}$ reduction was carried out over the $\mathrm{ZnO}$ NRA/C- $x$ nanohybrids and ZnO NRA under visible light irradiation. Fig. 7 shows that the activities of all the ZnO NRA/C- $x$ nanohybrids for evolving $\mathrm{CH}_{4}$ and/or $\mathrm{CO}$ were higher than those of the ZnO NRA. As discussed above, rapid transfer of photoelectrons from the ZnO NRA to the carbon layer occurred in the ZnO NRA/C- $x$ nanohybrids, which could account for the in- creased photocatalytic activity. The ZnO NRA/C-01 sample exhibited the highest photocatalytic ability among the four $\mathrm{ZnO}$ NRA/C- $x$ nanohybrids. Decreasing the carbon coating amount provided insufficient protection to the ZnO NRA, and the carbon-doping effect was insufficient to enhance absorption. Thus, the lower amount of incorporated carbon resulted in the lower photocatalytic activity of the ZnO NRA/C-005 nanohybrid. Further increasing the carbon coating amount enhanced the visible light absorption of the ZnO NRA/C- $x$ nanohybrids. For example, the ZnO NRA/C-03 sample exhibited the highest visible light absorption ability, as shown in Fig. 3. The enhanced light absorption mainly originated from the thick carbon layer coating. An excessively thick layer could block incident light from the surface-active sites of the ZnO NRA, leading to a decrease in photocatalytic activity [52].

To confirm the repeatability and stability of the $\mathrm{ZnO}$ NRA/C- $x$ nanohybrids, four consecutive runs of the photocatalytic $\mathrm{CO}_{2}$ reduction over the $\mathrm{ZnO} \mathrm{NRA} / \mathrm{C}-01$ nanohybrid were carried out under visible light irradiation. After each 5-hour run, the light was turned off and the photoreactor was evacu-

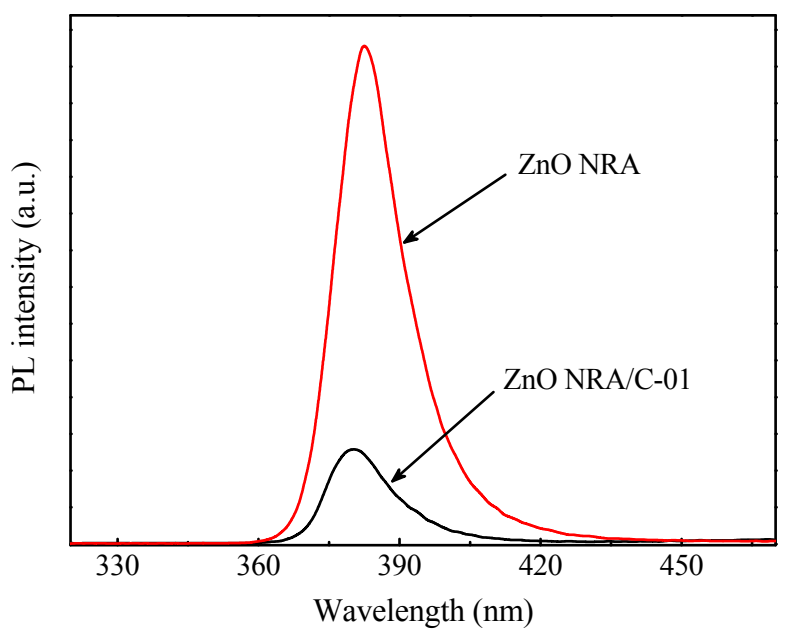

Fig. 6. PL spectra of the ZnO NRA/C-01 nanohybrid and ZnO NRA at room temperature. 

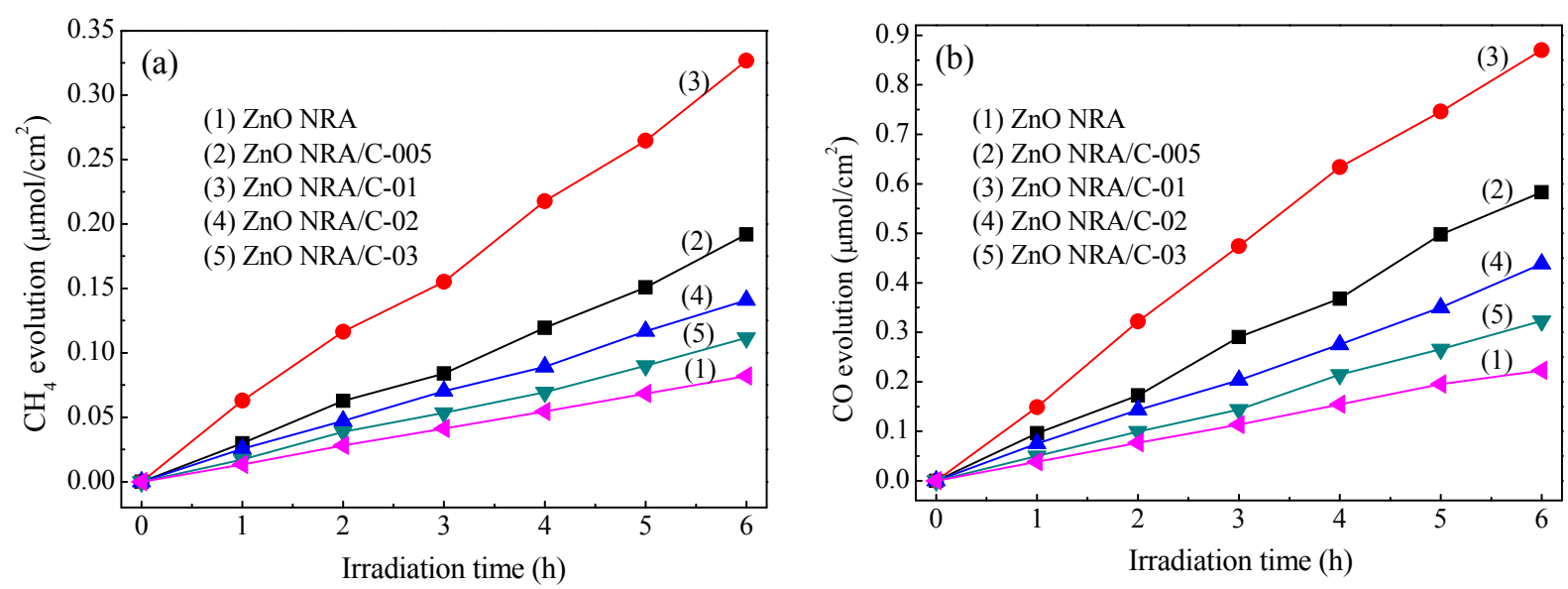

Fig. 7. (a) $\mathrm{CH}_{4}$ and (b) $\mathrm{CO}$ evolution over $\mathrm{ZnO}$ NRA and $\mathrm{ZnO}$ NRA/C- $x(x=005,01,02$, and 03$)$ as a function of irradiation time under visible light.

ated before refilling with $\mathrm{CO}_{2}$ and $\mathrm{H}_{2} \mathrm{O}(3 \mathrm{~mL})$. Fig. 8 shows that there were no obvious decreases in the yields of $\mathrm{CH}_{4}$ and $\mathrm{CO}$ after four runs, which demonstrated the stable photocatalytic activity of the ZnO NRA/C-01 nanohybrid. Further XPS measurements of the $01 s$ spectrum of ZnO NRA/C-01 showed that the amounts of surface lattice $\mathrm{O}$ and $-\mathrm{OH}$ decreased, while the amounts of adsorbed $\bullet \mathrm{O}_{2}{ }^{-}$species increased and the associated XPS peaks shifted to lower energy, as the reaction proceeded. It was believed that surface lattice $\mathrm{O}$ and $-\mathrm{OH}$ were converted into $\bullet \mathrm{O}_{2}{ }^{-}$during the photoreaction. There was very little difference in the profile of the $01 s$ XPS spectrum of the $\mathrm{ZnO}$ NRA/C-01 nanohybrid before and after reaction (data not shown), which indicated the high stability of the ZnO NRA/C- $x$ nanohybrids during the photocatalytic reaction. In comparison, a similar test conducted on the ZnO NRA sample showed an obvious decrease in the photoactivity after reaction for $5 \mathrm{~h}$. The above-mentioned results demonstrated that the photocorrosion and/or oxidation of the ZnO NRA were inhibited. This was attributed to the protection provided by the suitably thick carbon layer coated on the ZnO NRA. Similar observations have been reported for $\mathrm{TiO}_{2}$ nanolayer/CdS nanorod array [53] and $\mathrm{TiO}_{2}$ nanolayer/CdS-sensitized $\mathrm{ZnO}$ nanorod array composite

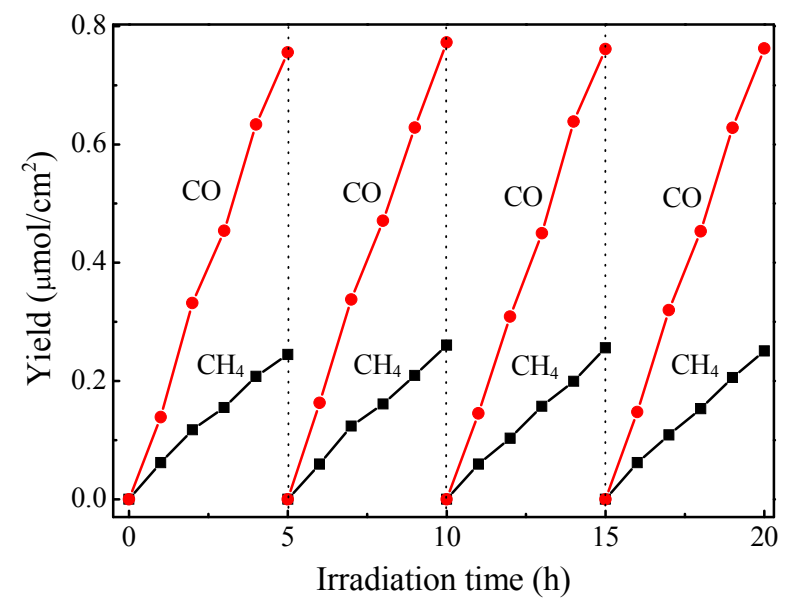

Fig. 8. Consecutive runs for the photoreduction of $\mathrm{CO}_{2}$ over the $\mathrm{ZnO}$ NRA/C-01 nanohybrid under visible light irradiation. structures [54], the photoactivity and photostability of which were improved by coating with a $\mathrm{TiO}_{2}$ layer.

We then carried out a series of control experiments to clarify the reaction mechanism of $\mathrm{CO}_{2}$ photoreduction with $\mathrm{H}_{2} \mathrm{O}$ over the ZnO NRA/C-01 nanohybrid. When the experiment was performed in the dark or in the absence of the photocatalyst, $\mathrm{CO}$ and $\mathrm{CH}_{4}$ could not be detected. This indicated that both light and the photocatalyst were required to generate $\mathrm{CO}$ and/or $\mathrm{CH}_{4}$. We performed another control experiment by replacing $\mathrm{CO}_{2}$ with pure Ar gas, while keeping the same amount of $\mathrm{H}_{2} \mathrm{O}$ in the reactor. Only a trace amount of hydrogen from water splitting was detected, implying that the $\mathrm{C}$ and $\mathrm{H}$ sources were $\mathrm{CO}_{2}$ and $\mathrm{H}_{2} \mathrm{O}$, respectively. In yet another control experiment, a $\mathrm{Zn} / \mathrm{C}$ foil sample (i.e., $\mathrm{Zn}$ foil coated with a graphitic carbon layer) was prepared for $\mathrm{CO}_{2}$ photoreduction under similar experimental conditions. $\mathrm{CH}_{4}$ and $\mathrm{CO}$ could not be detected, which excluded the possibility of $\mathrm{CH}_{4}$ and/or $\mathrm{CO}$ originating from the graphitic carbon.

Based on the above experimental results and discussion, we propose a mechanism for the photocatalytic $\mathrm{CO}_{2}$ reduction over the ZnO NRA/C- $x$ nanohybrids (Scheme 2). Upon light irradiation, electron/hole $\left(\mathrm{e}^{-} / \mathrm{h}^{+}\right)$pairs are generated on the surface of the ZnO NRA. The electrons quickly transfer to the graphitic carbon layer, initiating the reduction of $\mathrm{CO}_{2}$ with $\mathrm{H}_{2} \mathrm{O}$ into $\mathrm{CO}$, $\mathrm{CH}_{4}$, and $\mathrm{H}_{2}$. The holes remaining at the valence band of the ZnO NRA are supposed to oxidize water. Experimentally, we did not detect the expected oxidative product $\mathrm{O}_{2}$. Most likely, the oxidative product preferentially adopted the state of absorbed $\bullet \mathrm{O}_{2}{ }^{-}$in the form of $-\mathrm{Zn}-\mathrm{O}-\mathrm{O}-\mathrm{Zn}-$ [47]. To clarify the mechanism of the photocatalytic $\mathrm{CO}_{2}$ reduction over the $\mathrm{ZnO}$ NRA/C- $x$ nanohybrids, further experiments need to be carried out to detect products in the liquid phase. These experiments will form part of our future studies.

The photocatalytic reduction of chemically stable $\mathrm{CO}_{2}$ is a complex process involving $\mathrm{C}=0$ covalent bond breaking and $\mathrm{C}-\mathrm{H} / \mathrm{C}-\mathrm{C}$ bond formation $[5,26,55]$. The ZnO NRA/C- $x$ nanohybrid photocatalyst possesses several advantages for photocatalytic $\mathrm{CO}_{2}$ reduction. These include favorable ballistic electron transport capability in the 1-D ZnO nanorods. On the $\mathrm{ZnO}$ 


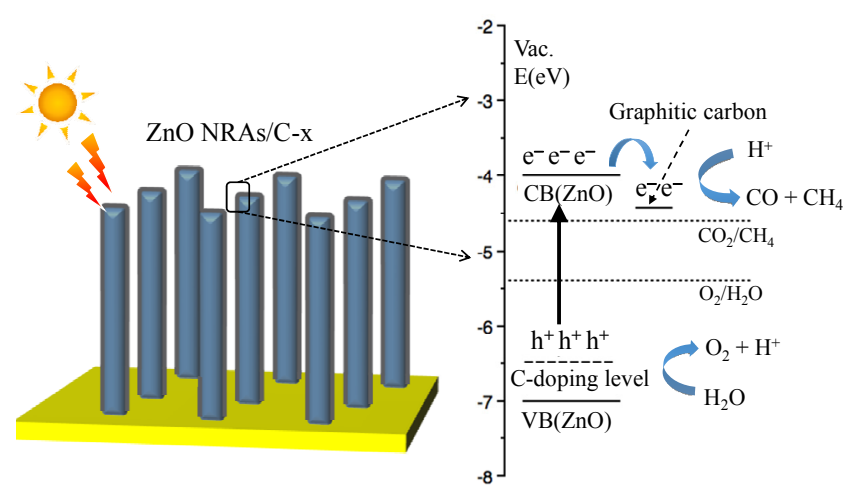

Scheme 2. Schematic of the mechanism of the photocatalytic conversion of $\mathrm{CO}_{2}$ into $\mathrm{CO}$ and/or $\mathrm{CH}_{4}$ over the $\mathrm{ZnO}$ NRA/C- $x$ nanohybrids.

NRA surface, the graphitic carbon layer further enhances charge carrier separation. In addition, the doped C $2 p$ level above the $02 p$ orbital in the valence band extends the absorption of the ZnO NRA/C- $x$ nanohybrids into the visible region. These advantages result in the ZnO NRA/C- $x$ nanohybrids showing favorable photocatalytic activity, in terms of both band engineering (carbon doping effect) and photoreaction kinetics (charge carrier separation and transport).

\section{Conclusions}

We synthesized graphitic-carbon-mediated visible-light-responsive ZnO NRA/C- $x$ on zinc foil via a modified hydrothermal method. By calcining the pre-synthesized ZnO NRAs and different amounts of glucose as a carbon source at a suitable hydrothermal temperature, we obtained ZnO NRA/C- $x$ nanohybrids. Compared with the ZnO NRA, the nanohybrids exhibited increased optical absorption and photostability due to the carbon-doping and carbon-coating effects. Charge carrier separation and transport in the ZnO NRA/C- $x$ nanohybrids was enhanced compared with in the ZnO NRA, because of the graphitic carbon layer coated on the ZnO NRA surface. As a result, the photocatalytic activity of the $\mathrm{ZnO}$ NRA/C- $x$ nanohybrids for $\mathrm{CO}_{2}$ reduction was improved. These findings demonstrate that graphitic carbon mediation is an effective and feasible way to improve the photostability, charge carrier separation, absorption range, and photocatalytic activity of semiconductor-based photocatalysts.

\section{References}

[1] A. Fujishima, K. Honda, Nature, 1972, 238, 37-38.

[2] Z. G. Zou, J.H. Ye, K. Sayama, H. Arakawa, Nature, 2001, 414, 625-627.

[3] M. Halmann, Nature, 1978, 275, 115-116.

[4] D. F. Wang, A. Pierre, M. G. Kibria, K. Cui, X. G. Han, K. H. Bevan, H. Guo, S. Paradis, A. R. Hakima, Z. T. Mi, Nano Lett., 2011, 11, 2353-2357.

[5] A. Sarkar, E. Gracia-Espino, T. Wågberg, A. Shchukarev, M. Mohl, A. R. Rautio, O. Pitkänen, T. Sharifi, K. Kordas, J. P. Mikkola, Nano Res., 2016, 9, 1956-1968.

[6] M. Marszewski, S. W. Cao, J. G. Yu, M. Jaroniec, Mater. Horizons, 2015, 2, 261-278.

[7] Q. J. Xiang, B. Cheng, J. G. Yu, Angew. Chem. Int. Ed., 2015, 54, 11350-11366.

[8] J. X. Low, B. Cheng, J. G. Yu, Appl. Surf. Sci., 2017, 392, 658-686.

[9] G. S. Li, D. Q. Zhang, J. C. Yu, Environ. Sci. Technol., 2009, 43, 7079-7085.

[10] G. Hitoki, T. Takata, J. N. Kondo, M. Hara, H. Kobayashi, K. Domen, Chem. Commun., 2002, 1698-1699.

[11] X. Wei, T. F. Xie, L. L. Peng, W. Fu, J. S. Chen, Q. Gao, G.Y. Hong, D. J. Wang, J. Phys. Chem. C, 2011, 115, 8637-8642.

[12] Y. P. Bi, J. H. Ye, Chem. Commun., 2009, 6551-6553.

[13] E. Reisner, D. J. Powell, C. Cavazza, J. C. Fontecilla-Camps, F. A. Armstrong, J. Am. Chem. Soc., 2009, 131, 18457-18466.

[14] Y. J. Wang, R. Shi, J. Lin, Y. F. Zhu, Energy Environ. Sci., 2011, 4, 2922-2929.

[15] B. A. Parkinson, P. F. Weaver, Nature, 1984, 309, 148-149.

[16] L. L. Yin, M. Zhao, H. L. Hu, J. H. Ye, D. F. Wang, Chin. J. Catal., 2017, 38, 1307-1314.

[17] H. Bouzid, M. Faisal, F. A. Harraz, S. A. Al-Sayari, A. A. Ismail, Catal.

\section{Graphical Abstract}

Chin. J. Catal., 2018, 39: 973-981 doi: 10.1016/S1872-2067(18)63010-4

\section{Enhancing the photocatalytic activity and photostability of zinc oxide nanorod arrays via graphitic carbon mediation}

Xuewei Zhang, Xueliang Zhang, Xin Wang, Lequan Liu, Jinhua Ye, Defa Wang *

Tianjin University, China;

Collaborative Innovation Center of Chemical Science and

Engineering (Tianjin), China;

National Institute for Materials Science, Japan

Graphitic-carbon-mediated ZnO nanorod arrays (NRAs) are fabricated by calcining pre-synthesized ZnO NRAs with different amounts of glucose as a carbon source, via a hydrothermal method. The resulting nanohybrids exhibit enhanced photocatalytic activity and photostability for $\mathrm{CO}_{2}$ reduction under visible light irradiation.

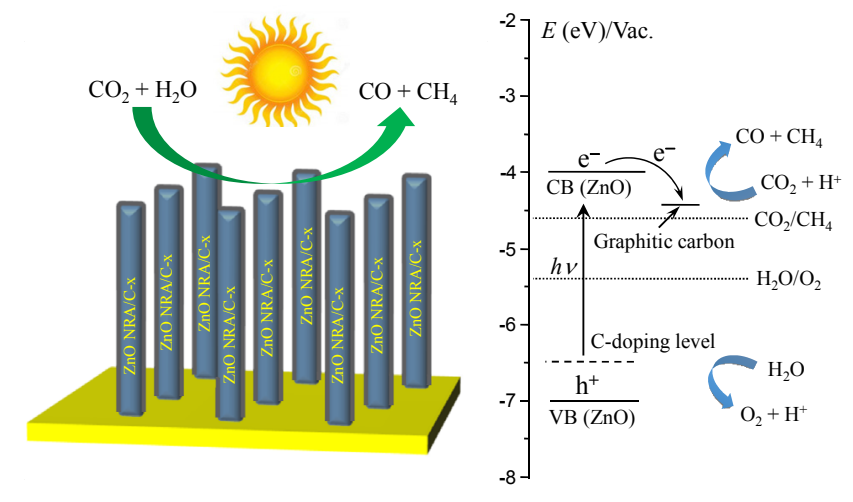


Today, 2015, 252, 20-26.

[18] W. L. Yu, J. F. Zhang, T. Y. Peng, Appl. Catal. B, 2016, 181, 220-227.

[19] M. J. Zhou, X. H. Gao, Y. Hu, J. F. Chen, X. Hu, Appl. Catal. B, 2013, 138-139, 1-8.

[20] S. T. Kochuveedu, Y. H. Jang, Y. J. Jang, D. H. Kim, J. Mater. Chem. A, 2013, 1, 898-905.

[21] J. Shim, J. K. Kim, K. S. Lee, C. L. Lee, M. Ma, W. K. Choi, J. Y. Hwang, H. Y. Yang, B. Angadi, J. H. Park, K. Yu, D. I. Son, Nano Energy, 2016, $25,9-17$.

[22] H. B. Fu, T. G. Xu, S. B. Zhu, Y. F. Zhu, Environ. Sci. Technol,, 2008, 42, 8064-8069.

[23] L. W. Zhang, H. Y. Cheng, R. L. Zong, Y. F. Zhu, J. Phys. Chem. C, 2009, 113, 2368-2374.

[24] H. Zhang, R. L. Zong, Y. F. Zhu, J. Phys. Chem. C, 2009, 113, $4605-4611$.

[25] X. Y. Zhang, J. Q. Qin, R. R. Hao, L. M. Wang, X. Shen, R. C. Yu, S. Limpanart, M. Z. Ma, R. P. Liu, J. Phys. Chem. C, 2015, 119, 20544-20554.

[26] S. W. Liu, J. H. Wang, J. G. Yu, RSC Adv., 2016, 6, 59998-60006.

[27] F. X. Wang, L. Liang, L. Shi, M. S. Liu, J. M. Sun, Dalton Trans., 2014, $43,16441-16449$.

[28] Y. G. Lin, Y. K. Hsu, Y. C. Chen, L. C. Chen, S. Y. Chen, K. H. Chen, Nanoscale, 2012, 4, 6515-6519.

[29] S. Cho, J. W. Jang, J. S. Lee, K. H. Lee, CrystEngComm, 2010, 12, 3929-3935.

[30] D. F. Wang, Z. G. Zou, J. H. Ye, Chem. Mater., 2005, 17, 3255-3261.

[31] D. J. Yang, H. W. Liu, Z. F. Zheng, Y. Yuan, J. C. Zhao, E. R. Waclawik, X. B. Ke, H. Y. Zhu, J. Am. Chem. Soc., 2009, 131, 17885-17893.

[32] T. Wang, R. Lü, P. Zhang, C. J. Li, J. L. Gong, Nanoscale, 2015, 7, 77-81.

[33] C. L. Zhang, M. F. Shao, F. Y. Ning, S.M. Xu, Z. H. Li, M. Wei, D. G. Evans, X. Duan, Nano Energy, 2015, 12, 231-239.

[34] A. I. Hochbaum, P. D.Yang, Chem. Rev., 2010, 110, 527-546.

[35] G. M. Wang, X. Y. Yang, F. Qian, J. Z. Zhang, Y. Li, Nano Lett, 2010, 10, 1088-1092.

[36] J. B. Mu, C. L. Shao, Z. C. Guo, Z. Y. Zhang, M. Y. Zhang, P. Zhang, B.
Chen, Y. C. Liu, ACS Appl. Mater. Interfaces, 2011, 3, 590-596.

[37] C. Han, M. Q. Yang, B. Weng, Y. J. Xu, Phys. Chem. Chem. Phys., 2014, 16, 16891-16903.

[38] Y. Guo, H. S. Wang, C. L. He, L. J. Qiu, X. B. Cao, Langmuir, 2009, 25, 4678-4684.

[39] H. Yu, H.C. Zhang, H. Huang, Y. Liu, H. T. Li, H. Ming, Z. H. Kang, New J. Chem., 2012, 36, 1031-1035.

[40] S. Akir, A. Hamdi, A. Addad, Y. Coffinier, R. Boukherroub, A. Dakhlaoui Omrani, Appl. Surf. Sci., 2017, 400, 461-470.

[41] J. Q. Qin, X. Y. Zhang, Y. N. Xue, N. Kittiwattanothai, P. Kongsittikul, N. Rodthongkum, S. Limpanart, M. Z. Ma, R. P. Liu, Appl. Surf. Sci., 2014, 321, 226-232.

[42] Y. G. Peng, J. L. Ji, D. J. Chen, Appl. Surf. Sci., 2015, 356, 762-768.

[43] Q. Tang, W. J. Zhou, J. M. Shen, W. Zhang, L. F. Kong, Y. T. Qian, Chem. Commun., 2004, 712-713.

[44] P. C. Eklund, J. M. Holden, R. A. Jishi, Carbon, 1995, 33, 959-972.

[45] D. R. Dreyer, S. Park, C. W. Bielawski, R. S. Ruoff, Chem. Soc. Rev., 2010, 39, 228-240.

[46] O. Akhavan, Carbon, 2011, 49, 11-18.

[47] T. G. Xu, L. W. Zhang, H. Y. Cheng, Y. F. Zhu, Appl. Catal. B, 2011, 101, 382-387.

[48] N. Li, G. Liu, C. Zhen, F. Li, L. L. Zhang, H. M. Cheng, Adv. Funct. Mater., 2011, 21, 1717-1722.

[49] J. P. Liu, Y. Y. Li, R.M. Ding, J. Jiang, Y. Y. Hu, X. X. Ji, Q. B. Chi, Z. H. Zhu, X. T. Huang, J. Phys. Chem. C, 2009, 113, 5336-5339.

[50] E. Rokhsat, O. Akhavan, Appl. Surf. Sci., 2016, 371, 590-595.

[51] J. M. Zhang, M. Vasei, Y. H. Sang, H. Liu, J. P. Claverie, ACS Appl. Mater. Interfaces, 2016, 8, 1903-1912.

[52] Y. Hu, X. H. Gao, L. Yu, Y. R. Wang, J. Q. Ning, S. J. Xu, X. W. Lou, Angew. Chem. Int. Ed., 2013, 52, 5636-5639.

[53] L. P. Wu, Y. L. Zhang, X. J. Li, C. P. Cen, Phys. Chem. Chem. Phys., 2014, 16, 15339-15345.

[54] J. L. Ouyang, M. L. Chang, X. J. Li, J. Mater. Sci., 2012, 47, 4187-4193.

[55] Y. S. Liao, Z. N. Hu, Q. Gu, C. Xue, Molecules, 2015, 20, 18847-18855.

\title{
类石墨碳修饰提高 $\mathrm{ZnO}$ 纳米棒阵列光催化活性和光稳定性的研究
}

\author{
张学伟 ${ }^{\mathrm{a}}$, 张学亮 ${ }^{\mathrm{a}}$, 王 金坣 ${ }^{\mathrm{a}}$, 刘乐全 ${ }^{\mathrm{a}, \mathrm{b}}$, 叶金花 ${ }^{\mathrm{a}, \mathrm{b}, \mathrm{c}}$, 王德法 ${ }^{\mathrm{a}, \mathrm{b}},{ }^{*}$ \\ a 天津大学材料科学与工程学院, 天津市材料复合与功能化重点实验室, 先进陶瓷与加工技术教育部重点实验室, \\ 天津大学-NIMS 国际合作实验室, 天津300072, 中国 \\ ${ }^{\mathrm{b}}$ 天津化学化工协同创新中心, 天津 300072 , 中国 \\ ${ }^{\mathrm{c}}$ 日本国立物质材料研究机构材料纳米构筑学国际中心(WPI-MANA), 茨城县305-0044, 日本
}

摘要: 半导体光催化是一种理想的太阳能化学转化绿色技术, 可以实现水分解制氢和 $\mathrm{CO}_{2}$ 光还原制备碳氢化合物燃料. 氧 化锌 $(\mathrm{ZnO})$ 作为一种直接带隙半导体材料, 一方面具有性能优异、价格低廉、易制备等优点; 另一方面因光腐蚀而不稳定, 大大限制了该材料的实际应用. 本文提出了一种简单易行的类石墨碳修饰方法, 可以有效提高 $\mathrm{ZnO}$ 用于 $\mathrm{CO}_{2}$ 光还原的光 催化活性和稳定性.

首先采用水热法在金属锌片基底上生长 $\mathrm{ZnO}$ 纳米棒阵列 ( $\mathrm{ZnO}-\mathrm{NRA})$, 然后通过葡萄糖水热法进行不同含量的类石墨 碳 (C- $x$ ) 修饰, 形成 ZnO-NRA/C- $x$ 纳米复合结构, 同步实现碳包覆和碳掺杂. $\mathrm{X}$ 射线衍射结果表明, $\mathrm{ZnO}$ 纳米棒及 ZnO-NRA/C- $x$ 纳米复合结构都具有良好的纤锌矿型 (Wurtzite) 结构; 而拉曼散射则清楚地证实了类石墨碳的存在. 扫描 电子显微观察显示, 生长的 $\mathrm{ZnO}$ 纳米棒长度大约 2-5 $\mu \mathrm{m}$, 直径为 400-700 nm, 沿方向 [0001]生长, 端部由六个规则的 (103) 晶面组成, 进一步直观佐证了 $\mathrm{ZnO}$ 的典型纤锌矿型结构特征. 透射电子显微分析结果表明, ZnO-NRA/C- $x$ 纳米复合结构 中类石墨碳包覆层厚度大约为 $8 \mathrm{~nm} . \mathrm{ZnO}-\mathrm{NRA} / \mathrm{C}-\mathrm{x}$ 纳米复合结构的 $\mathrm{X}$ 射线光电子谱分析结果验证了 $\mathrm{C}-\mathrm{C}, \mathrm{C}-\mathrm{O}$ 和 $\mathrm{C}=\mathrm{O}$ 键的存在与碳的包覆层相对应; 而 $\mathrm{C}-\mathrm{O}-\mathrm{Zn}$ 键的出现则是由于碳在 $\mathrm{ZnO}$ 中掺杂所引起. 从紫外-可见吸收谱上可观察到 $\mathrm{ZnO}$ 的典型吸收带边位置约为 $385 \mathrm{~nm}$, 而碳的包覆和掺杂导致 ZnO-NRA/C- $x$ 纳米复合结构的吸收带边发生红移, 并且吸 
收背底明显提高.

电化学阻抗谱测试结果清楚地显示, ZnO-NRA/C- $x$ 纳米复合结构比单纯 ZnO-NRA 的电化学阻抗明显降低, 说明类石 墨碳包覆层大幅度提高了电导性能, 从而有利于光生载流子的分离和传输. 荧光分析结果也表明, 与单纯的 ZnO-NRA 相 比, ZnO-NRA/C- $x$ 纳米复合结构的苂光强度大幅度下降, 进一步证实了 $\mathrm{ZnO}-\mathrm{NRA} / \mathrm{C}-\mathrm{x}$ 纳米复合结构比单纯的 ZnO-NRA 更有利于光生载流子的分离和传输. 光电化学测试结果表明, $\mathrm{ZnO}-\mathrm{NRA} / \mathrm{C}-\mathrm{x}$ 纳米复合结构的瞬态光电流 4 倍于单纯的 $\mathrm{ZnO}-\mathrm{NRA}$, 而 $\mathrm{CO}_{2}$ 光还原性能测试也得到一致的结果. 长时间多循环 $\mathrm{CO}_{2}$ 光还原实验证实, $\mathrm{ZnO}-\mathrm{NRA} / \mathrm{C}-x$ 纳米复合结构 具有稳定的光催化活性和极好的光稳定性.

综上, 我们利用一种简单易行的水热法进行类石墨碳修饰, 成功开发了 ZnO-NRA/C- $x$ 纳米复合结构, 该结构因其优异 的光生电子和空穴的分离和迁移性能, 从而具有显著提升的 $\mathrm{CO}_{2}$ 光还原活性和光稳定性. 本工作证明, 类石墨碳修饰是一 种可以广泛借鉴的有效提升半导体材料光催化活性和光稳定性的可行方法.

关键词: 光催化; $\mathrm{ZnO}$ 纳米棒阵列; 类石墨碳; 电荷转移; 光稳定性; 二氧化碳还原

收稿日期: 2017-11-18. 接受日期: 2017-12-28. 出版日期: 2018-05-05.

*通讯联系人. 电话/传真: (022)27405065; 电子信箱: defawang@tju.edu.cn

基金来源：国家重点基础研究发展计划(973 计划, 2014CB239300); 国家自然科学基金(51572191, 21633004); 天津市自然科学基 金(13JCYBJC16600).

本文的电子版全文由Elsevier出版社在ScienceDirect上出版(http://www.sciencedirect.com/science/journal/18722067). 